\title{
Efficacy of an established marine protected area at sustaining a queen conch Lobatus gigas population during three decades of monitoring
}

\author{
Andrew S. Kough ${ }^{1, *}$, Heather Cronin ${ }^{2}$, Rachel Skubel ${ }^{3}$, Carolyn A. Belak ${ }^{4}$, \\ Allan W. Stoner ${ }^{5}$ \\ ${ }^{1}$ Daniel P. Haerther Center for Conservation and Research, John G. Shedd Aquarium, Chicago, IL 60605, USA \\ ${ }^{2}$ AIS Inc., 14 Barnabas Road, Marion, MA 02738, USA \\ ${ }^{3}$ Abess Center for Ecosystem Science and Policy, University of Miami, Miami, FL 33146, USA \\ ${ }^{4}$ California Department of Fish and Wildlife, Stockton, CA 95206, USA \\ ${ }^{5}$ Community Conch, Lopez Island, WA 98261, USA
}

\begin{abstract}
Marine Protected Areas (MPAs) are designed to conserve and preserve the ecosystems and cultural resources of the ocean. In theory, protected populations flourish, replenish adjacent regions, and are self-sustaining. However, describing the efficacy of MPAs requires long-term monitoring. Queen conch Lobatus gigas are iconic Caribbean denizens with populations that have been decimated by overfishing and are slow to rebound due to density-dependent breeding. The Exuma Cays Land and Sea Park (ECLSP) is a well-enforced, no-take, old, and large MPA. Surveys in 1994, 2011, and 2016 were used to track changes in the abundance, size, and age structure of conch within the park. Statistical models suggested that abundances of adults in $50 \mathrm{~km}$ of repeated towed-observer surveys had declined by $71 \%$ in 2016 relative to 2011 . Further, the remaining conch populations were associated with tidal channels, and these model results agreed with independent observations in $40 \mathrm{~km}$ of expanded survey area. Measurements of shell lip thickness, an estimator of relative age, showed an increase relative to 1994 with the greatest effect in 2016, indicating senescence. The ECLSP population appears to be slowly dying of old age, and an early life history process has been altered. Upstream populations have been heavily fished while habitats within the park remain productive, suggesting that low local retention and a lack of exogenous larval sources are driving the decline. A network of MPAs encompassing the entire life cycle and dispersal envelope of targeted organisms is needed for proper conch conservation. Surveys focused on tidal channels could locate candidate upstream populations of conch.
\end{abstract}

KEY WORDS: Queen conch $\cdot$ Marine protected area $\cdot$ Benthic survey $\cdot$ Senescence $\cdot$ Size $\cdot$ Age

\section{INTRODUCTION}

Marine Protected Areas (MPAs) are an established and popular conservation tool for populations of marine fish and invertebrates. In theory, an effective MPA anchors an ecosystem by reducing or removing major anthropogenic impacts, allowing the habitat and organisms contained within it to thrive and their populations to increase and spill over to replenish adjacent unprotected areas. However, many of these or-

${ }^{*}$ Corresponding author: andrew.kough@gmail.com ganisms have complex life cycles, with development and dispersal occurring in pelagic waters that may or may not be protected (Cowen \& Sponaugle 2009). Thus, to harbor a sustainable population, MPAs must be planned to account for patterns of connectivity between disparate populations that are linked by larval exchange and adult spillover (Botsford et al. 2009).

There is evidence of MPAs successfully replenishing the stocks that they are intended to protect. This has been shown based upon larval recruitment back restricted. Authors and original publication must be credited. 
into a reserve (Harrison et al. 2012, Almany et al. 2013), microchemistry (Chittaro \& Hogan 2013), and population genetics (Christie et al. 2010, D'Aloia et al. 2015). However, the shape and function of a larval dispersal network can change, depending on the species (Holstein et al. 2014) and the timescales (Kough \& Paris 2015) being considered. While biophysical modelling suggests that connectivity patterns can be relatively consistent over larger timescales (Le Corre et al. 2015, Kough et al. 2016), recruitment patterns are often highly variable in time (Siegel et al. 2008), and larval sources fluctuate accordingly. For example, variable patterns of local retention have been described using parentage analysis (SaenzAgudelo et al. 2012) and marked recruits (Cuif et al. 2015). There is also direct evidence of locations with primarily exogenous recruitment sources (Andrello et al. 2013, Nanninga et al. 2015) that would be poor MPA candidate locations. Habitat quality and environmental conditions certainly interact with larval supply in replenishing benthic populations (Lipcius et al. 2008). While even isolated populations with low larval supply may be replenished, given enough time (Gilmour et al. 2013), it can be argued that connectivity likely dominates habitat quality as the primary mechanism of efficacy for self-sustaining MPAs in some systems (Pinsky et al. 2012, White et al. 2014, D'Agostini et al. 2015). Overall, a review of movement patterns suggests that the most effective MPAs encompass both adult and larval dispersal while also containing the appropriate mix of key habitats for any given species (Green et al. 2015). If a species has limited movement as an adult, the ecological efficacy of a MPA in protecting a population should depend on both the habitats protected and the supply of larvae.

Queen conch Lobatus gigas move relatively short distances as adults versus as larvae, making them ideal indicators of MPA function. After a larval phase lasting between 2 and $5 \mathrm{wk}$, queen conch in The Bahamas recruit into shallow nursery habitats that have the proper biological communities (typically seagrasses) and are situated within tidal channels that bring in clear, cool, flood tide waters (Stoner 2003). As the individuals mature, they leave the nursery habitat and move into deeper water (Stoner \& Schwarte 1994), and as adults have home ranges that can encompass many habitat types (Doerr \& Hill 2013). Conch can live to approximately $30 \mathrm{yr}$ and grow to about $30 \mathrm{~cm}$ in shell length (McCarthy 2007). It takes roughly $3.5 \mathrm{yr}$ for an individual to reach terminal shell length after recruitment, at which point the shell spreads out and forms a flared lip (Appeldoorn 1988). Conch shells grow thicker throughout their lives, giving a relative estimate of age that can be noninvasively measured. However, growth patterns and shell characteristics are influenced by the environment and are spatially and temporally variable. In The Bahamas, sexual maturity is first observed in conch with a shell lip thickness near $10 \mathrm{~mm}$ (Stoner et al. 2012a), and 50\% maturity occurs near $15 \mathrm{~mm}$ (Community Conch unpubl. data). Conch populations are slow to recover following decline (Glazer \& Berg 1994), likely because of density-dependent breeding (Stoner et al. 2012b) and perhaps due to Allee effects (Stoner \& Ray-Culp 2000, but see Gascoigne \& Lipcius 2004). In summary, although conch rapidly reach a terminal length and grow a flared lip, sexual maturity occurs later, with reproductive potential peaking and then decreasing as individuals age. In addition, queen conch is a species of national and international conservation concern (Acosta 2006), firmly embedded in Bahamian culture as a popular cuisine and valuable export product.

Due to their longevity, limited adult dispersal, and ease of observation, queen conch is an ideal focal species to evaluate how a population changes through time in an MPA. The Exuma Cays Land and Sea Park (ECLSP) is an appropriate MPA due to its age, size, and regular enforcement. Further, as the ECLSP conch population has been studied for decades, our study is supported by a long history of work, and it has been suggested that the park population is in senescence (Stoner et al. 2012c). Here, our goal was to examine how the abundance, age, and size structure of the conch population in the ECLSP changed during surveys in 1994, 2011, and 2016. In addition, we identified factors for conch abundance that could estimate potential population sizes to guide surveys and conservation planning elsewhere in the Caribbean. To accomplish our goals, we expanded a towed observer conch survey in time and space to estimate population density changes, and measured conch shells to estimate changes in the size and age structure of the park population. The temporal longitude of our dataset is a strength (Hughes et al. 2017) that lets us better describe MPA efficacy at sustaining a population of queen conch.

\section{MATERIALS AND METHODS}

\section{Study site}

Our study area is within the Exuma island chain, which consists of about 365 cays (islands) in the central Bahamas (Fig. 1). To the east of the island chain 


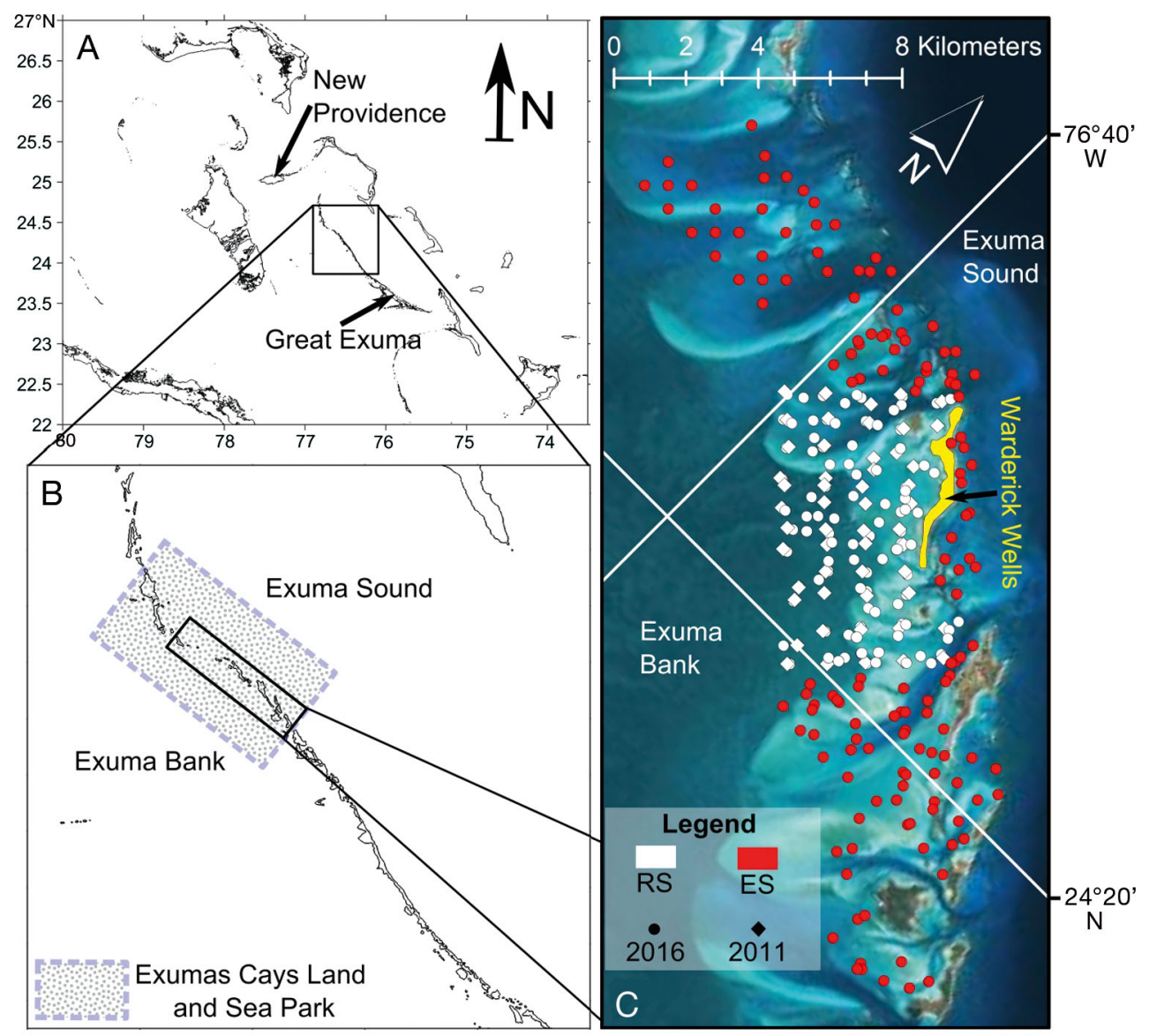

Fig. 1. (A) Study area within the Exuma Cays Land and Sea Park (ECLSP) of The Bahamas. The Exuma Cays are within The Bahamas and near population centers New Providence to the north and Great Exuma to the South. (B) The ECLSP, a well-enforced no-take marine protected area since the $1980 \mathrm{~s}$, is located centrally in the island chain and protects habitat from the deep-water Exuma Sound and the shallow Exuma Bank. Towed-observer surveys focused on the Bank side of the ECLSP in an area adjacent to the park headquarters on Warderick Wells. (C) The repeated survey (RS; white) was bounded by an area previously surveyed in 2011 (diamonds). The expanded survey (ES; red) applies the same methodology in previously unsurveyed areas

lies a $30 \mathrm{~m}$ deep shelf that extends for $1 \mathrm{~km}$ before plunging $>2000 \mathrm{~m}$ into the Exuma Sound. To the west of the island chain lies the shallow $(<10 \mathrm{~m})$ Exuma Bank, extending between 30 and $70 \mathrm{~km}$ to the Tongue of the Ocean. The islands thus divide our study site into 2 locations: the bank side and the sound side. Banks are typically sandy and sparsely vegetated with seagrass and macroalgae, while the shelf bordering the Exuma Sound is home to many hard-bottom habitats including gorgonian plains and coral reefs (Stoner et al. 1998). Currents run approximately NNW in the sound along the shelf (Colin 1995). Deep tidal channels separate the islands and bring cool, clear water onto the banks. The islands are typically sparsely inhabited, with the largest human population in Georgetown in Great Exuma at the southern end of the island chain (see Fig. 1A). However, the most populated island in The Bahamas is New Providence, home to the capital city of Nassau, approximately $50 \mathrm{~km}$ from the northern end of the Exumas (see Fig. 1A).

In the center of the $200 \mathrm{~km}$ island chain is the ECLSP, the oldest MPA in The Bahamas (see Fig. 1B). It fits each of the criteria of the NAPOLI standard (no-take, well-enforced, old, large, and isolated) for optimal MPAs (Edgar et al. 2014). The ECLSP follows the Exuma Islands from Shroud Cay in the north to Conch Cut in the south, and habitat falling within $7 \mathrm{~km}$ on both the bank and the sound sides of the cays is protected as a no-take reserve. The ECLSP was established in 1958 by the Bahamian government under the National Trust Act (Chiappone \& Sealey 2000). Although not initially closed to fishing, in 1986 the park was designated as protected and today it remains a no-take reserve consistently monitored by a park warden and onsite Bahamian National Defense Force staff. The park includes habitat for marine species of national conservation interest including Nassau grouper Epinephelus striatus, spiny lobster Panulirus argus, and queen conch Lobatus gigas. Previous work has suggested that Nassau grouper are more abundant within the ECLSP (Sluka et al. 1997) and that populations of conch, lobster, and grouper within the reserve are likely sources of larvae (Stoner \& Ray 1996, Lipcius et al. 2008,) and/or adults (Kanciruk \& Herrnkind 1978, Dahlgren et al. 2016) to areas outside park boundaries. 


\section{Survey methods}

We used towed observer surveys to assess the density and distribution of queen conch populations over the banks adjacent to Warderick Wells (WW; see Fig. 1C) within the ECLSP. The 2016 data (tows and measurements) were collected during late May when adult conch were actively mating (Aldana Aranda et al. 2014), and thus captured similar environmental and ecological conditions as previous surveys (Stoner \& Ray 1996, Stoner et al. 2012c). Following previous protocols (Stoner \& Ray 1996, Stoner et al. 2012c), an observer was towed behind a skiff $\left(\sim 4 \mathrm{~km} \mathrm{~h}^{-1}\right)$ and recorded queen conch in each of 3 classes (juvenile, subadult, adult) that fell within a $6 \mathrm{~m}$ band beneath the observer. In the survey we defined juveniles as conch $<15 \mathrm{~cm}$ in length, subadults as $>15 \mathrm{~cm}$ in length but lacking a flared lip, and adults as individuals with flared lips. Observers rode snorkel tow boards to facilitate easy diving and searching for conch. The tow board was attached to the skiff with $7 \mathrm{~m}$ of line, and the start and endpoints of tows were recorded by the boat's GPS (echoMAP 50; Garmin).

Survey effort in 1994 and 2011 consisted of $1 \mathrm{~km}$ tows following 12 transects perpendicular to the long axis of WW (i.e. SW to NE) and extending $5 \mathrm{~km}$ out over the banks. The area within which these tows fell is hereafter referred to as the repeated survey (RS). We enlarged the survey area on both sides of the RS and approximately doubled the area wherein we searched for conch in the ECLSP. We refer to this expansion as the expanded survey (ES). We used a sampling scheme recently employed to quantify conch abundance in 16 different locations around the Bahamas (Stoner 2015, A. S. Kough unpubl. data) to guide the ES. Here, survey areas were stratified into $1^{\prime} \times 1^{\prime}$ grids of latitude and longitude that served as the units for each survey and were sampled by $1 \mathrm{~km}$ of tow effort. Five $200 \mathrm{~m}$ tows proceeding in random cardinal directions from fixed points within each grid generated a stratified random design in order to increase chances of observing patchily-distributed queen conch.

\section{Population age and size structure}

Shell measurements (shell length and lip thickness) were taken to describe adult age within aggregations encountered on the banks (roughly SW of WW) and on the shelf (sound side; roughly NE of WW). Measurements were taken of at least 50 individuals from large aggregations (an aggregation being a grouping of $>100$ adult conch). We measured queen conch from 3 adult aggregations on the sound side $(\mathrm{n}=253)$ and 3 on the bank $(\mathrm{n}=312)$ adjacent to WW for comparison with previous surveys. We also measured adult conch $(\mathrm{n}=51)$ which the warden had confiscated from illegal fishers within the park, and had deposited within swimming distance of our quarters. This opportunistic sampling of conch confiscated from fishers provided an additional perspective of harvest selection (within ECLSP, but with unknown harvest location). We measured shell length from the tip of the spire to the siphonal canal. Shell lip thickness was measured following Appeldoorn (1988): within the mid-lateral region between 3 and $4 \mathrm{~cm}$ from the lip edge to avoid misreadings from damaged and eroded shells.

\section{Statistical analyses}

We evaluated how abundances of conch changed between the previous survey in 2011 and the current survey in 2016 within the RS. Counts of rare species are often over-dispersed and zero-inflated (Thompson 2004); thus, we used generalized linear modeling (GLM) to compare our repeated years with a focus on effect size. This enabled us to evaluate how year interacted with other terms. We were specifically interested in how the distance from a tow transect midpoint to the nearest channel (connecting the bank to the sound) shaped conch distributions. To account for the zero-inflated and over-dispersed distribution of conch counts we used a negative binomial model ('glm.nb'; package MASS; R Core Team 2016). Using Akaike's information criterion (AIC), we evaluated which combination of factors (categorical factor 'year' and continuous factors 'tow length' and 'channel distance') were included in the best-fit model for predicting conch of each class. Additionally, because we expanded our survey beyond the RS, we were able to test how the resulting model performed against an independent dataset (i.e. the ES). This offered further validation of the fit of the model over a larger area, and confidence in its conclusions.

Using GLMs, we examined how location and year affected shell measurements. For both sets of shell measurements, we examined the effect of the categorical factors year (levels 1994, 2011, and 2016) and location (levels bank and sound) as well as their interactions on predicted shell length or lip thickness. Measurements were approximately normally distributed, so a Gaussian link was used. Measurements from the bank, sound, and confiscated conch 
in 2016 were considered with the factor source (bank, sound, confiscated).

All statistics were performed using R (version 3.3.2; R Core Team 2016); the data and code are provided in Supplement 1 at www.int-res.com/articles/suppl/ m573p177_supp/.

\section{RESULTS}

\section{Survey methods}

We towed underwater conch observers for $\sim 98 \mathrm{~km}$ within the ECLSP on 244 individual tows during May 2016, expanding the spatial scope over both fine (within a survey unit) and broad (increasing the survey area) scales (Fig. 1). Conch were patchily distributed across their habitat and a direct comparison of density would have been heavily influenced by the few large aggregations encountered in each survey. For example, during the 2011 survey $35 \%$ of the adults within the RS survey area were found on a single tow, and during the 2016 RS survey $90 \%$ of the juveniles were found on a single tow. During 2011, adults were detected in $40 \%$ of the tows, subadults in $54 \%$ and juveniles in $33 \%$ within the RS survey $\left(\mathrm{n}_{\text {tows }}\right.$ $=52$ ). In the 2016 iteration of the RS ( $\left.n_{\text {tows }}=95\right)$ we saw a decrease in the percent of tows with adults to $33 \%$, a decrease to $39 \%$ with subadults, and a decrease to $13 \%$ with juveniles. The RS survey effort was $\sim 53 \mathrm{~km}$ towed in 2011 and $~ 54 \mathrm{~km}$ towed in 2016. In the ES (Fig. $1 C$, red circles; $n_{\text {tows }}=149$ ) we detected adults in $43 \%$ of the tows, subadults in $30 \%$, and juveniles in $15 \%$. We used statistical models to focus on effect size to describe these population trends.

\section{Stock status in the ECLSP}

The best fit model for adult conch abundance included the factors year and channel distance (Table 1). The main effect of year was a significant

Table 1. Effects changing queen conch density in repeated surveys over the Exuma Cays Land and Sea Park (ECLSP) banks. A generalized linear model (GLM) with a negative binomial link estimated the effects of year (categorical and relative to 2011 survey), tow length (m), and distance from tidal channel ( $m_{\text {; Fig. }}$ ) on observations of queen conch of 3 sizes classes in a repeated survey. Coefficients are shown for each factor included in each model. Model fit was assessed relative to Akaike's information criterion (AIC). Results are shown \pm SE; significant terms $(\mathrm{p}<0.05)$ in bold

\begin{tabular}{|c|c|c|c|c|c|c|c|c|}
\hline & 1 & 2 & 3 & 4 & 5 & 6 & 7 & 8 \\
\hline \multicolumn{9}{|l|}{ Adult } \\
\hline AIC & 522.04 & 523.94 & 526.86 & 528.58 & 537.54 & 539.4 & 540.26 & 541.61 \\
\hline Intercept & $3.92 \pm 0.54$ & $3.69 \pm 0.87$ & $2.13 \pm 0.58$ & $3.12 \pm 0.45$ & $2.32 \pm 0.41$ & $2.03 \pm 0.87$ & $0.74 \pm 0.54$ & $1.71 \pm 0.25$ \\
\hline Year (2016) & $-1.36 \pm 0.47$ & $-1.27 \pm 0.56$ & & & $-1.24 \pm 0.51$ & $-1.11 \pm 0.61$ & & \\
\hline Tow length & & $\begin{array}{r}2.26 \times 10^{-4} \\
\pm 7.01 \times 10^{-4}\end{array}$ & $\begin{array}{r}1.25 \times 10^{-3} \\
\pm 6.03 \times 10^{-4}\end{array}$ & & & $\begin{array}{r}2.79 \times 10^{-4} \\
\pm 7.61 \times 10^{-4}\end{array}$ & $\begin{array}{r}1.18 \times 10^{-3} \\
\pm 6.48 \times 10^{-4}\end{array}$ & \\
\hline $\begin{array}{l}\text { Channel } \\
\text { distance }\end{array}$ & $\begin{array}{r}-1.34 \times 10^{-3} \\
\pm 2.61 \times 10^{-4}\end{array}$ & $\begin{array}{r}-1.34 \times 10^{-3} \\
\pm 2.61 \times 10^{-4}\end{array}$ & $\begin{array}{r}-1.26 \times 10^{-3} \\
\pm 2.63 \times 10^{-4}\end{array}$ & $\begin{array}{r}-1.25 \times 10^{-3} \\
\pm 2.68 \times 10^{-4}\end{array}$ & & & & \\
\hline \multicolumn{9}{|l|}{ Subadult } \\
\hline AIC & 534.36 & 536.29 & 540.15 & 541.7 & 575.71 & 577.69 & 578.41 & 579.8 \\
\hline Intercept & $1.95 \pm 0.44$ & $1.85 \pm 0.66$ & $2.99 \pm 0.34$ & $3.16 \pm 0.43$ & $0.55 \pm 0.45$ & $0.61 \pm 0.74$ & $1.55 \pm 0.21$ & $1.76 \pm 0.35$ \\
\hline Year (2016) & & $0.10 \pm 0.43$ & & $-0.26 \pm 0.38$ & & $-0.07 \pm 0.51$ & & $-0.34 \pm 0.44$ \\
\hline Tow length & $\begin{array}{r}1.40 \times 10^{-3} \\
\pm 4.61 \times 10^{-4}\end{array}$ & $\begin{array}{r}1.44 \times 10^{-3} \\
\pm 5.45 \times 10^{-4}\end{array}$ & & & $\begin{array}{r}1.24 \times 10^{-3} \\
\pm 5.41 \times 10^{-4}\end{array}$ & $\begin{array}{r}1.21 \times 10^{-3} \\
\pm 6.43 \times 10^{-4}\end{array}$ & & \\
\hline $\begin{array}{l}\text { Channel } \\
\text { distance }\end{array}$ & $\begin{array}{r}-1.56 \times 10^{-3} \\
\pm 2.14 \times 10^{-4}\end{array}$ & $\begin{array}{r}-1.57 \times 10^{-3} \\
\pm 2.14 \times 10^{-4}\end{array}$ & $\begin{array}{r}-1.51 \times 10^{-3} \\
\pm 2.18 \times 10^{-4}\end{array}$ & $\begin{array}{r}-1.51 \times 10^{-3} \\
\pm 2.19 \times 10^{-4}\end{array}$ & & & & \\
\hline \multicolumn{9}{|l|}{ Juvenile } \\
\hline AIC & 269.5 & 270.68 & 284.7 & 284.72 & 284.91 & 286.76 & 298.49 & 300.49 \\
\hline Intercept & $-1.30 \pm 0.77$ & $-0.88 \pm 1.06$ & $3.13 \pm 0.72$ & $2.35 \pm 0.57$ & $-3.14 \pm 0.77$ & $-3.03 \pm 1.13$ & $0.56 \pm 0.33$ & $0.56 \pm 0.56$ \\
\hline Year (2016) & & $-0.52 \pm 0.63$ & $-0.52 \pm 0.63$ & & & $-0.23 \pm 0.71$ & & $-1.51 \times 10^{-3} \pm 0.70$ \\
\hline Tow length & $\begin{array}{r}3.94 \times 10^{-3} \\
\pm 8.36 \times 10^{-4}\end{array}$ & $\begin{array}{r}3.84 \times 10^{-3} \\
\pm 9.53 \times 10^{-4}\end{array}$ & & & $\begin{array}{r}4.62 \times 10^{-3} \\
\pm 1.00 \times 10^{-3}\end{array}$ & $\begin{array}{r}4.04 \times 10^{-3} \\
\pm 1.00 \times 10^{-3}\end{array}$ & & \\
\hline $\begin{array}{l}\text { Channel } \\
\text { distance }\end{array}$ & $\begin{array}{r}-1.68 \times 10^{-3} \\
\pm 3.46 \times 10^{-4}\end{array}$ & $\begin{array}{r}-1.74 \times 10^{-3} \\
\pm 3.50 \times 10^{-4}\end{array}$ & $\begin{array}{r}-1.74 \times 10^{-3} \\
\pm 3.50 \times 10^{-4}\end{array}$ & $\begin{array}{r}-1.74 \times 10^{-3} \\
\pm 3.75 \times 10^{-4}\end{array}$ & & & & \\
\hline
\end{tabular}



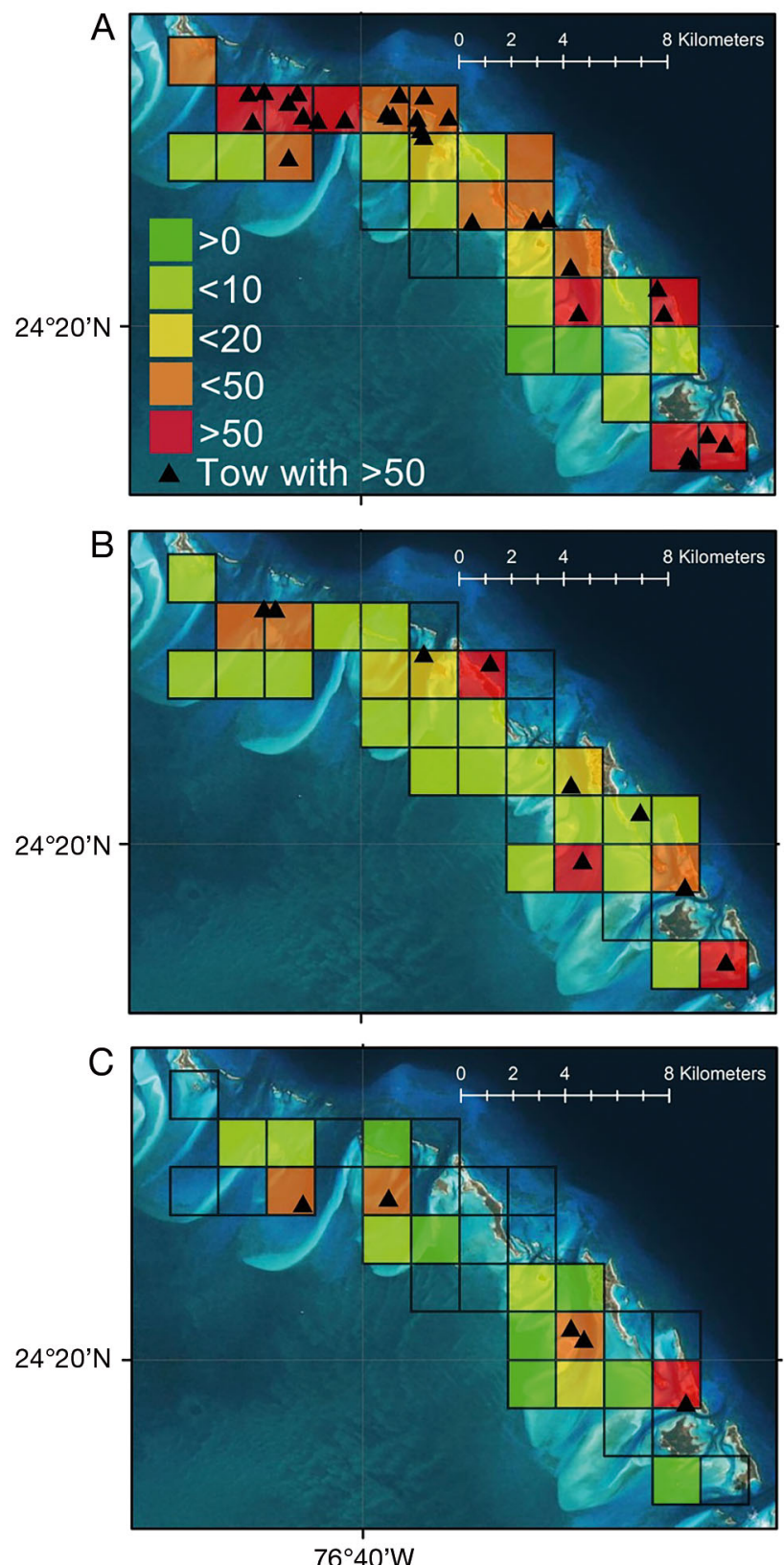

Fig. 2. Mean queen conch density (no. ha ${ }^{-1}$ ) through survey area, calculated from tows within each grid, showing estimated densities of (A) adults, (B) subadults, and (C) juveniles. The transect midpoints of individual tows with high concentrations of conch are shown with triangles. Juvenile abundance, while shown here to provide context, is best estimated using other methods because young conch are often buried in the substrate

decrease in adult abundance relative to 2011. There was a $71 \%$ decrease in adult abundance relative to 2011 with a confidence interval of 16 to $96 \%$. The main effect of channel distance was a significant decrease in adult abundance of $0.02 \%$ per meter farther away from a channel. The best-fitting models for subadults and juveniles included channel distance and tow length (Table 1). Year was not present in the best-fitting models for either subadult or juvenile abundance, suggesting that these conch age classes have changed little since 2011. As with adults, the main effect of channel distance was a significant decrease in both subadult and juvenile abundance. Thus overall, the effect of channel distance was negative for each class of conch, supporting associations between conch habitat preference and tidal flow. Conch of any age class are unlikely to be encountered at distances greater than $\sim 3 \mathrm{~km}$ from a channel. Tow length had a positive effect on predicted conch abundance, an intuitive result given that more conch would be expected to be observed on longer tows.

We assessed how well our best-fit model predicted conch abundance using an independent comparison with our ES. $\triangle$ AIC between the full model and bestfit model for each age class was $<2$ (Table 1 ), thus we used it to predict conch abundance in the ES. Given the high number of observed zero abundances in the ES, we $\log (x+1)$ transformed the data prior to comparison. The predicted abundance of adults was significantly correlated (Pearson correlation; $\mathrm{n}=149, \mathrm{r}=$ $0.30, p=1.8 \times 10^{-4}$ ) with the observed abundance in the independent survey (i.e. the ES), giving us confidence in the model (see Fig. S1 in Supplement 2 at www.int-res.com/articles/suppl/m573p177_supp/).

An important consideration for management is how much of the population is aggregated in densities projected to be high enough for breeding. Adult densities $>50$ conch ha ${ }^{-1}$ were encountered during 3 tows in an area covering $\sim 1 \%$ of the RS survey area during 2016. This was a decrease from high densities of adult conch on 4 tows covering $~ 8 \%$ of the survey area during the 2011 RS survey. The original survey during 1994 had high densities of adult conch on 12 tows that covered $\sim 34 \%$ of the area surveyed. Qualitatively, the amount of surveyed habitat supporting densities of adult conch in numbers high enough to mate decreased in each survey from 1994 through 2016 and is now orders of magnitude lower. However, in the ES, which included additional deepwater channels, we found adults within $15 \%$ of the area surveyed in densities high enough to mate (Fig. 2A). We found mating adults on individual tows even in areas where the average density through the survey unit was not considered high enough to support breeding (Fig. 2A; triangles outside of highest mean density projections).

The long duration of this study allowed us to compare how size (shell length) and age structure (lip thickness) changed at 3 points over 22 years (1994, 

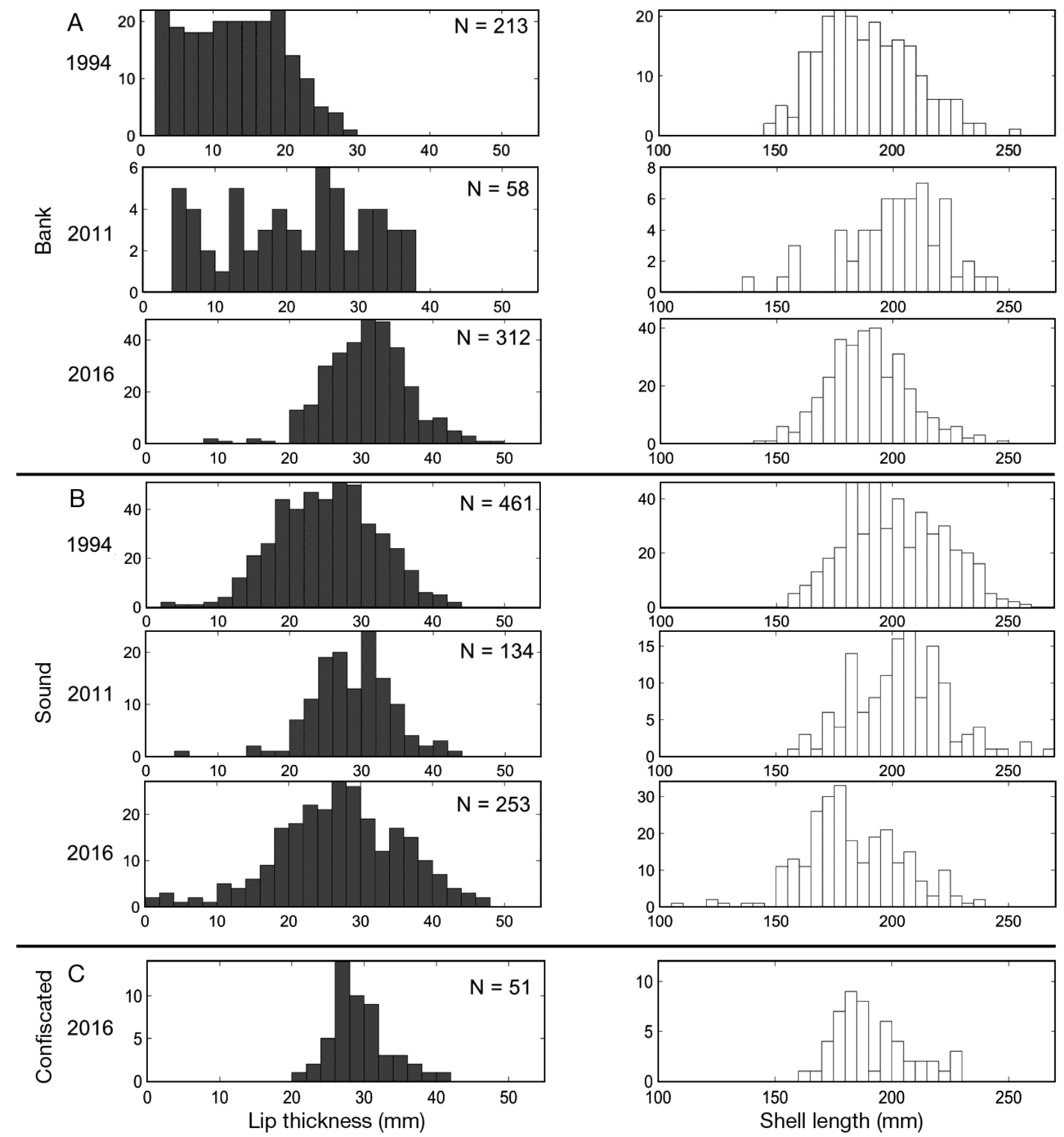

Fig. 3. Shell lip thickness and shell length measured in adult queen conch within the Exuma Cays Land and Sea Park (ECLSP). Histograms show individuals with flared lips that were measured in aggregations on (A) the bank and (B) the sound sides of the ECLSP in 2016 and compared with previous surveys $(1994,2011)$, and (C) conch confiscated from fishers

2011, and 2016; Fig. 3). Lip thickness, an indicator of relative age, was predicted relative to the categorical factors year (3 levels: 1994, 2011, 2016) and side (2 levels: bank and sound) as well as their interactions. The best-fitting model included the significant effects of year, side, and their interactions (Table 2).
The main effect of year was an increase in lip thickness relative to 1994, with the greatest effect in 2016. Thus, the lip thickness of the population increased in each survey showing that the population is aging. The main effect of side was an increase in lip thickness relative to the bank; conch with thicker lips 
Table 2. Changes in queen conch lip thickness between adult populations on the bank and the sound sides of the Exuma Cays Land and Sea Park (ECLSP) in 1994, 2011, and 2016. A generalized linear model (GLM) with a Gaussian link with the categorical factors year (relative to 1994), side (bank or sound, relative to bank), and interactions predicted lip thickness (mm) measured in adult conch. Results are shown $\pm \mathrm{SE}$; N/A: not available; all terms are significant $(\mathrm{p}<0.5)$

\begin{tabular}{|c|c|c|c|c|c|c|c|c|}
\hline & 1 & 2 & 3 & 4 & 5 & 6 & 7 & 8 \\
\hline AIC & 9730.4 & 9730.4 & 9730.4 & 9730.4 & 10061 & 10172 & 10384 & 10419 \\
\hline Intercept & $12.49 \pm 0.48$ & $12.49 \pm 0.48$ & $12.49 \pm 0.48$ & $26.45 \pm 0.44$ & $17.63 \pm 0.43$ & $20.86 \pm 0.32$ & $22.90 \pm 0.37$ & $24.60 \pm 0.24$ \\
\hline Side (sound) & $12.26 \pm 0.59$ & $12.26 \pm 0.59$ & & & $4.75 \pm 0.44$ & & $2.89 \pm 0.48$ & \\
\hline Year 2011 & $8.09 \pm 1.05$ & & $8.09 \pm 1.05$ & & $4.90 \pm 0.65$ & $4.96 \pm 0.68$ & & \\
\hline Year 2016 & $17.73 \pm 0.63$ & & $17.73 \pm 0.63$ & & $8.84 \pm 0.46$ & $7.68 \pm 0.47$ & & \\
\hline Side (sound): year 1994 & & & $12.26 \pm 0.59$ & $-1.70 \pm 0.55$ & & & & \\
\hline Side (sound): year 2011 & $-4.73 \pm 1.26$ & $3.36 \pm 0.69$ & $7.53 \pm 1.11$ & $1.66 \pm 0.76$ & & & & \\
\hline Side (sound): year 2016 & $-16.03 \pm 0.84$ & $1.70 \pm 0.55$ & $-3.77 \pm 0.60$ & N/A & & & & \\
\hline Side (bank): year 1994 & & & & $-13.96 \pm 0.66$ & & & & \\
\hline Side (bank): year 2011 & & $8.09 \pm 1.05$ & & $-5.86 \pm 1.03$ & & & & \\
\hline Side (bank): year 2016 & & $17.73 \pm 0.63$ & & $3.77 \pm 0.60$ & & & & \\
\hline
\end{tabular}

Table 3. Changes in queen conch shell length between adult populations on the bank and the sound sides of the Exuma Cays Land and Sea Park (ECLSP) in 1994, 2011, and 2016. A generalized linear model (GLM) with a Gaussian link with categorical factors year (relative to 1994), side (bank or sound, relative to bank), and interactions predicted shell length (mm) measured in adult conch. N/A: not available; significant terms $(\mathrm{p}<0.05)$ in bold

\begin{tabular}{|c|c|c|c|c|c|c|c|c|}
\hline & 1 & 2 & 3 & 4 & 5 & 6 & 7 & 8 \\
\hline AIC & 12740 & 12740 & 12740 & 12740 & 12796 & 12800 & 12895 & 12916 \\
\hline Intercept & $188.51 \pm 1.38$ & $188.51 \pm 1.38$ & $188.51 \pm 1.38$ & $182.35 \pm 1.27$ & $194.84 \pm 1.11$ & $196.73 \pm 0.79$ & $189.92 \pm 0.87$ & $193.18 \pm 0.56$ \\
\hline Side (sound) & $12.01 \pm 1.67$ & $12.01 \pm 1.67$ & & & $2.76 \pm 1.13$ & & $5.52 \pm 1.14$ & \\
\hline Year 2011 & $11.94 \pm 2.98$ & & $11.94 \pm 2.98$ & & $5.25 \pm 1.68$ & $5.29 \pm 1.68$ & & \\
\hline Year 2016 & $0.45 \pm 1.78$ & & $0.45 \pm 1.78$ & & $-10.01 \pm 1.20$ & $-10.68 \pm 1.17$ & & \\
\hline Side (sound): year 1994 & & & $12.01 \pm 1.67$ & $18.18 \pm 1.57$ & & & & \\
\hline Side (sound): year 2011 & $-9.77 \pm 3.58$ & $2.17 \pm 1.97$ & $2.25 \pm 3.16$ & $20.35 \pm 2.15$ & & & & \\
\hline Side (sound): year 2016 & $-18.62 \pm 2.38$ & $-18.18 \pm 1.57$ & $-6.61 \pm 1.69$ & N/A & & & & \\
\hline Side (bank): year 1994 & & & & $6.16 \pm 1.87$ & & & & \\
\hline Side (bank): year 2011 & & $11.94 \pm 2.98$ & & $18.10 \pm 2.93$ & & & & \\
\hline Side (bank): year 2016 & & $0.45 \pm 1.79$ & & $6.61 \pm 1.69$ & & & & \\
\hline
\end{tabular}

(which were likely older) were found on the sound side of the park. An interaction existed between year and side of the park. This interaction diminishes the main effect of year for sound-side populations where lip thickness increased less relative to conch on the bank in each year. For example, conch on the shelf in 2016 were only $1.7 \mathrm{~mm}$ thicker than in 1994, while conch on the bank in 2016 were $17 \mathrm{~mm}$ thicker than in 1994.

Shell length, an indicator of conch size, was predicted relative to the categorical factors year (3 levels: 1994, 2011, 2016) and side (2 levels: bank and sound) as well as their interactions. The best-fitting model included the significant effects of year, side, and the interactions (Table 3). The main effect of side was an increase in shell length in conch from the sound relative to the bank, with bigger conch found on the sound side of the park. The main effect of year was an increase in shell length in 2011 relative to 1994, however there was no significant effect of 2016. There was also an interaction between year and side. Thus, overall conch size increased between the first 2 surveys yet did not change from 1994 to 2016 on the bank. However, on the sound side a significant negative interaction tempered the increase from 1994 to 2011 and created a decrease in size in 2016.

\section{Confiscated conch}

Confiscated individuals from one day's catch were measured to estimate the size and age of conch selected by fishers. We used a GLM with a Gaussian link to examine how the categorical factor source 
(3 levels: bank, sound, confiscated) associated with varying lip thickness and shell length. As above, location had a significant influence on conch shells measured during 2016, with thinner (mean \pm SE: intercept $=30.2 \pm 0.40 \mathrm{~mm}$; sound $=-3.78 \pm 0.60 \mathrm{~mm}$ ) and smaller (intercept $=189.0 \pm 1.06 \mathrm{~mm}$; sound $=$ $-6.61 \pm 1.60 \mathrm{~mm}$ ) shells found on the sound side relative to the bank side. The effect of confiscated was a larger $(2.12 \pm 2.9 \mathrm{~mm})$ and thinner $(-1.32 \pm 1.07 \mathrm{~mm})$ shell relative to the bank side. However, the effect of confiscated was not significant in either case and we were unable to suggest the location from which fishers took the conch.

\section{DISCUSSION}

To properly evaluate MPA performance and suitability for a given species, 3 critical pieces of information are needed: (1) lifetime fecundity, (2) local retention rates, and (3) survival post-recruitment (Burgess et al. 2014). These 3 factors can be approximated by measuring the long-term changes in abundance and age structure within a population, as we have done in this study. Each repeated survey of conch in the ECLSP over 22 yr shows a further decline in adult density, with the current survey showing a decline of perhaps $71 \%$ in just $5 \mathrm{yr}$. If the primary source of adult mortality within the population is old age, as in the ECLSP where no-take fishing is enforced, then surveys over timespans exceeding the maximum longevity of the species should describe whether a population is stable (age structure does not change), growing (age structure becoming younger), and/or senescing (age structure becoming older). Since old conch are still fecund, and habitat changes that alter survival have not been documented within known ECLSP nursery habitat, a potential cause of a senescing population would be local retention rates too low to sustain the population coupled with a lack of exogenous sources of larvae. Population densities decreased and the average age of adult conch significantly increased during each survey, suggesting that the conch population within the ECLSP is slowly dying of old age.

The carrying capacity of a patch, manifesting itself as reproductive output, may be more important than connectivity when planning protections for a metapopulation (Cabral et al. 2016); a highly connected site that produces few larvae may not sustain or contribute to a metapopulation. In patches with high dispersal and low local retention, spatially specific demographic rates can have an increased effect on how a patch contributes to the metapopulation (Figueira 2009). Given that the ECLSP population is aging, the cause of decline is likely tied to early life history. A key demographic rate for conch is high juvenile mortality prior to the formation of a larger shell that offers predation relief (Iversen et al. 1986, 1990, Ray et al. 1994). The ECLSP has one of the densest populations of grouper in the Caribbean (Mumby et al. 2011), likely as a result of the effective no-take reserve regulations. If conch predator populations are also thriving, including those of sharks and rays already benefiting from a Bahamian ban on harvest through some core portions of their range (Graham et al. 2016), it may tip mortality rates to the point where few immature conch survive to maturity. A greatly increased mortality rate of juveniles and subadults would also likely result in a population slowly dying of old age. The decline in conch abundance within the ECLSP is likely the result of a complex suite of both demographic and connectivity changes within the larger metapopulation (Puckett \& Eggleston 2016), including the removal of upstream larval sources.

An important consideration for conch, and other slow-moving gastropods, is to readily find a mate. For queen conch the density thresholds recommended by scientists and policy makers to support breeding is between 50 and 100 adult conch ha ${ }^{-1}$ (Stoner et al. 2012a). Our ES survey expanded on both sides of the original RS survey within the ECLSP and included additional habitat that harbored high densities of breeding adults. The highest densities of adult conch that we found were near channels farther to the west and south in the ES area; 28 tows in our ES survey showed densities high enough to promote mating (Fig. 2A). We noted copulation in these areas and others during our tows where we passed over smaller but sexually active samples of the population (authors' pers. obs.). The regulations and enforcement of the ECLSP enable adult conch to live to ages approaching their maximum. As a result, the ECLSP successfully protects an adult conch population as is the case for MPAs in the Turks and Caicos (Bene \& Tewfik 2003), Mexico (Baqueiro Cárdenas \& Aldana Aranda 2010), and Belize (Acosta 2006).

However, despite the occurrence of many breeding adults in the ECLSP, and evidence of breeding adults in even higher densities away from the boundaries of the original survey (i.e. the RS), we still observed a senescing population. This suggests that the amount of larval retention within the park adjacent to WW is inadequate to support a self-sustaining population, and/or a demographic rate has changed within the 
park which hinders young adults from reaching maturity and joining mating aggregations. If the decline is caused by inadequate larval supply, it appears that conch are reliant on larval transport over scales exceeding $23 \mathrm{~km}$, the maximum distance between our survey sites. Mounting work suggests that coastal oceanography features retain larvae and reduce dispersal kernels (Nickols et al. 2015, Hameed et al. 2016), yet this may not be the case for queen conch within a large but isolated marine reserve featuring a continuum of habitat from banks to coast and pelagic in The Bahamas. If the decline is caused by a change to a key demographic rate, such as greater immature mortality, it suggests that conservation strategies that prioritize protecting highquality habitat may not work for all species over greater timescales. Given that (1) the habitat remains productive for other species in the ECLSP, (2) no phase shifts have been documented within the park's habitat, and (3) upstream populations have long been largely beneath the density required for reproduction (Stoner \& Ray 1996), we hypothesize that the declines are likely caused by inadequate larval supply.

Our statistical models reinforce the ecological importance of channels for conch. Tidal channels were positively associated with conch abundance in all age classes (Table 1), yielding valuable informa-

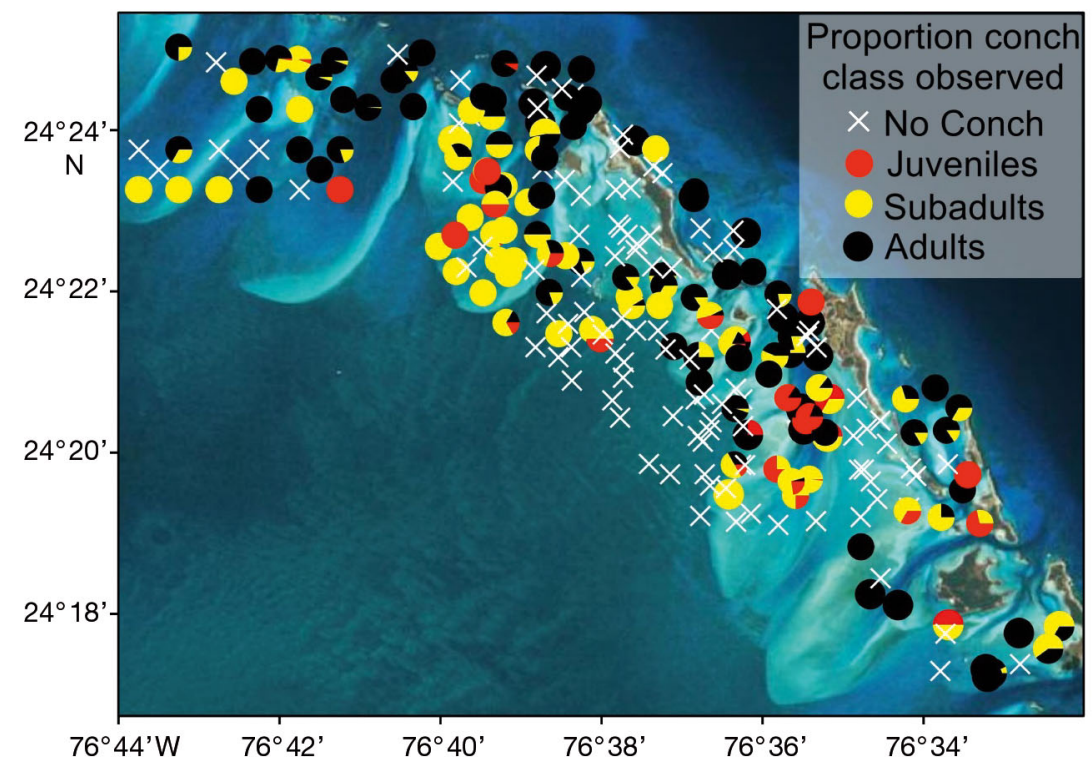

Fig. 4. Distribution of queen conch age classes throughout the survey area in the Exuma Cays Land and Sea Park (ECLSP) during May 2016. Adult (black), subadult (yellow), and juvenile (red) conch were observed by snorkelers on tows $(\mathrm{n}=244)$ between 200 and $1000 \mathrm{~m}$ in length. Pie charts depicting the proportion of conch in each class were placed on the transect midpoint of each tow where conch were observed, and white crosses on tow midpoints where no conch were seen. Conch move as they mature, from nurseries on the banks through channels towards the Exuma sound tion for conservation planning. Juvenile conch tend to recruit into shallow nursery habitats, and then disperse outwards as subadults (Stoner 2003). Subadults grow into adults which move towards deep-water channels from the bank side of the park out onto the sound side. We observed these patterns during our surveys in the park (Fig. 4). During our surveys we also collected depth measurements and habitat imagery, factors which may be interacting with channels. Future models will include these terms as factors of conch abundance throughout The Bahamas.

Continued monitoring of the population is required to both detect change and evaluate MPA efficacy at sustaining a viable conch population. Given the dwindling population around The Bahamas, reflected in a $29 \%$ decrease in conch landing weight from 2012 to 2014 (L. Gittens, Bahamas Department of Marine Resources pers. comm.), surveys in the primary fishing grounds are needed to provide current population statuses to inform management. Further, locating remaining populations is a crucial first step in identifying the larval connectivity pathways and patches with high reproductive potential that maintain the broader conch metapopulation. Bahamian fishers know where large conch populations are and can therefore guide survey efforts. To quantify conch populations we recommend using towed observer surveys, or alternative technology where snorkeling is not feasible (Boman et al. 2016), coupled with statistical models. Our abundance model suggests that when local knowledge is not available, surveys should focus in areas proximate to tidal channels. Repeatedly taking measurements of adult conch shells demonstrates how population age and size structure changes over time, and supplements abundance data. Thus, shell measurements can provide explanations for a population's trajectory.

Regular enforcement within a reserve helps reduce fishing mortality, yet some level of poaching is unavoidable. Our opportunistic sampling of conch confiscated from poachers by the park warden allowed us to evaluate which conch fishers were selecting. While the confiscated conch did not appear significantly different from either bank or sound side populations, they were the largest animals observed. This is a logical finding and 
fishers would be expected to seek out the largest individuals to maximize profit. Large aggregations of adult conch occurred in relatively shallow waters $(<3 \mathrm{~m})$ over the ECLSP banks facilitating the nontaxing collection of hundreds of individuals with $1 \mathrm{~h}$ of effort (authors' pers. obs.), likely a tempting opportunity for poachers. The similarity of the confiscated conch to both bank and sound side populations suggests that if there are not resources available to measure in situ individuals, measuring harvested animals may be a good indicator of the population age structure, bearing in mind that fishermen are likely selecting larger individuals. Indeed, conch shell middens are known to provide useful information on local populations and changes in fishing practices (Stoner 1997).

Well-enforced, old, large, isolated, no-take MPAs should be most effective at maintaining ecosystem function and species demography (Edgar et al. 2014), yet here we provide evidence that these traits do not always protect a species in a MPA over longer timescales. We suggest that larval connectivity may usurp these qualities over time for some species. Indeed, over smaller regional scales of $\sim 100 \mathrm{~km}$, oceanographic connectivity has been shown to correlate with genetic structure (Thomas et al. 2015). Populations connected by surface-advected coral propagules also have genetic structure shaped by oceanography (Baums et al. 2006, Wood et al. 2016). A review of dispersal focused on reef fish (with a similar length pelagic dispersal phase as conch) suggested that scales of protection should be equivalent to double the dispersal potential (Green et al. 2015). However, the continuing decline we observed in the ECLSP suggests that in some areas source and sink dynamics outweigh generalizations and can cause inefficacy (D'Agostini et al. 2015). Given that queen conch are a species of national conservation concern, the identification and protection of upstream sources of conch for the ECLSP should be a priority for ensuring a self-sustaining conch population in the future if our hypotheses are correct. The international community has committed to protect about $30 \%$ of the world's coastline by 2030 to bolster sustainable fishing practices (Hilborn 2016). In The Bahamas, a nation with $3542 \mathrm{~km}$ of coastline, adhering to these recommendations would mean $1063 \mathrm{~km}$ of protection compared with the current $\sim 350 \mathrm{~km}$. However, while a small nation by land area $\left(\sim 11000 \mathrm{~km}^{2}\right)$ Bahamians are stewards to a vast area of shallow $(<10 \mathrm{~m}$; $\left.\sim 136000 \mathrm{~km}^{2}\right)$ and deep $\left(<50 \mathrm{~m} ; \sim 300000 \mathrm{~km}^{2}\right)$ marine banks that are not necessarily associated with shorelines (Carew \& Mylroie 1997). These areas war- rant consideration for protection. The government and people of The Bahamas are pursuing new protected areas, and embarking on a 'conch-servation' campaign (http://bnt.bs/science/conchservation/) so the future is hopeful, as long as plans take into consideration data on larval connectivity, protect nursery habitats near tidal channels, and include regular monitoring to evaluate efficacy.

Acknowledgements. This work was funded by the John G. Shedd Aquarium with support from the Bahamas National Trust. David Dorsett, Henry Haley, and Ken Marshal facilitated fieldwork and made us welcome in the park. The crew of the R/V 'Coral Reef II', K. Stump, and R. Gericke provided logistical support. C. Knapp provided advice on study design and manuscript content. NOAA's National Undersea Research Program, the Caribbean Marine Research Center, Community Conch, and The Bahamas Department of Marine Resources funded earlier surveys. Three anonymous reviewers and the handling editor, R. Lipcius, guided and strengthened the manuscript.

\section{LITERATURE CITED}

Acosta CA (2006) Impending trade suspensions of Caribbean queen conch under CITES: a case study on fishery impacts and potential for stock recovery. Fisheries (Bethesda, Md) 31:601-605

Aldana Aranda D, Oxenford HA, Bissada C, Enriquez Díaz $M$ and others (2014) Reproductive patterns of queen conch, Strombus gigas (Mollusca, Gastropoda), across the wider Caribbean region. Bull Mar Sci 90:813-831

Almany GR, Hamilton RJ, Bode M, Matawai M and others (2013) Dispersal of grouper larvae drives local resource sharing in a coral reef fishery. Curr Biol 23:626-630

Andrello M, Mouillot D, Beuvier J, Albouy C, Thuiller W, Manel S (2013) Low connectivity between Mediterranean marine protected areas: a biophysical modeling approach for the dusky grouper Epinephelus marginatus. PLOS ONE 8:e68564

Appeldoorn RS (1988) Age determination, growth, mortality, and age of first reproduction in adult queen conch, Strombus gigas, off Puerto Rico. Fish Res 6:363-378

Baqueiro Cárdenas E, Aldana Aranda D (2010) Histories of success for the conservation of populations of queen conch (Strombus gigas). Gulf Caribb Fish Inst 62: 306-312

Baums IB, Paris CB, Cherubin LM (2006) A bio-oceanographic filter to larval dispersal in a reef-building coral. Limnol Oceanogr 51:1969-1981

* Bene C, Tewfik A (2003) Biological evaluation of marine protected area: evidence of crowding effect on a protected population of queen conch in the Caribbean. Mar Ecol 24:45-58

*Boman EM, De Graaf M, Nagelkerke LAJ, Van Rijn J, Meijer M, Schloctern Z, Smaal A (2016) Underwater towed video: a novel method to estimate densities of queen conch (Lobatus gigas; Strombidae) across its depth range. J Shellfish Res 35:493-498

* Botsford LW, White JW, Coffroth MA, Paris CB and others (2009) Connectivity and resilience of coral reef metapop- 
ulations in marine protected areas: matching empirical efforts to predictive needs. Coral Reefs 28:327-337

Burgess SC, Nickols KJ, Griesemer CD, Barnett LAK and others (2014) Beyond connectivity: how empirical methods can quantify population persistence to improve marine protected-area design. Ecol Appl 24:257-270

Cabral RB, Gaines SD, Lim MT, Atrigenio MP, Mamauag SS, Pedemonte GC, Alino PM (2016) Siting marine protected areas based on habitat quality and extent provides the greatest benefit to spatially structured metapopulations. Ecosphere 7:e01533

Carew JL, Mylroie JE (1997) Geology of The Bahamas. In: Vacher HL, Quinn TM (eds) Geology and hydrogeology of carbonate islands. Developments in Sedimentology, Vol 54. Elsevier, Amsterdam, p 91-139

Chiappone M, Sealey KMS (2000) Marine reserve design criteria and measures of success: lessons learned from the Exuma Cays Land and Sea Park, Bahamas. Bull Mar Sci 66:691-705

Chittaro PM, Hogan JD (2013) Patterns of connectivity among populations of a coral reef fish. Coral Reefs 32:341-354

Christie MR, Tissot BN, Albins MA, Beets JP and others (2010) Larval connectivity in an effective network of marine protected areas. PLOS ONE 5:e15715

Colin PL (1995) Surface currents in Exuma Sound, Bahamas, and adjacent areas with reference to potential larval transport. Bull Mar Sci 56:48-57

* Cowen RK, Sponaugle S (2009) Larval dispersal and marine population connectivity. Annu Rev Mar Sci 1:443-466

Cuif M, Kaplan DM, Fauvelot C, Lett C, Vigliola L (2015) Monthly variability of self-recruitment for a coral reef damselfish. Coral Reefs 34:759-770

* D'Agostini A, Gherardi DFM, Pezzi LP (2015) Connectivity of marine protected areas and its relation with total kinetic energy. PLOS ONE 10:e0139601

D'Aloia CC, Bogdanowicz SM, Francis RK, Majoris JE, Harrison RG, Buston PM (2015) Patterns, causes, and consequences of marine larval dispersal. Proc Natl Acad Sci USA 112:13940-13945

* Dahlgren CP, Buch K, Rechisky E, Hixon MA (2016) Multiyear tracking of Nassau grouper spawning migrations. Mar Coast Fish 8:522-535

Noerr JC, Hill RL (2013) Home range, movement rates, and habitat use of queen conch, Strombus gigas, in St. John, US Virgin Islands. Caribb J Sci 47:251-259

*Edgar GJ, Stuart-Smith RD, Willis TJ, Kininmouth S and others (2014) Global conservation outcomes depend on marine protected areas with five key features. Nature 506:216-220

Figueira WF (2009) Connectivity or demography: defining sources and sinks in coral reef fish metapopulations. Ecol Modell 220:1126-1137

Gascoigne J, Lipcius RN (2004) Conserving populations at low abundance: delayed functional maturity and Allee effects in reproductive behaviour of the queen conch Strombus gigas. Mar Ecol Prog Ser 284:185-194

Gilmour JP, Smith LD, Heyward AJ, Baird AH, Pratchett MS (2013) Recovery of an isolated coral reef system following severe disturbance. Science 340:69-71

Glazer RA, Berg CJ (1994) Queen conch research in Florida: an overview. In: Appeldoorn RS, Rodriguez B (eds) Queen conch biology, fisheries, and mariculture. Fundación Cientifica Los Roques, Caracas, p 79-95

Graham F, Rynne P, Estevanez M, Luo J, Ault JS, Hammerschlag N (2016) Use of marine protected areas and exclu- sive economic zones in the subtropical western North Atlantic Ocean by large highly mobile sharks. Divers Distrib 22:534-546

* Green AL, Maypa AP, Almany GR, Rhodes KL and others (2015) Larval dispersal and movement patterns of coral reef fishes, and implications for marine reserve network design. Biol Rev Camb Philos Soc 90:1215-1247

Hameed SO, White JW, Miller SH, Nickols KJ, Morgan SG (2016) Inverse approach to estimating larval dispersal reveals limited population connectivity along $700 \mathrm{~km}$ of wave-swept open coast. Proc Biol Sci 283:20160370

*Harrison HB, Williamson DH, Evans RD, Almany GR and others (2012) Larval export from marine reserves and the recruitment benefit for fish and fisheries. Curr Biol 22: 1023-1028

Hilborn R (2016) Policy: marine biodiversity needs more than protection. Nature 535:224-226

*Holstein DM, Paris CB, Mumby PJ (2014) Consistency and inconsistency in multispecies population network dynamics of coral reef ecosystems. Mar Ecol Prog Ser 499: $1-18$

*Hughes BB, Beas-Luna R, Barner AK, Brewitt K and others (2017) Long-term studies contribute disproportionately to ecology and policy. Bioscience 67:271-281

Iversen ES, Jory DE, Bannerot SP (1986) Predation on queen conchs, Strombus gigas, in the Bahamas. Bull Mar Sci 39: $61-75$

Iversen ES, Bannerot SP, Jory DE (1990) Evidence of survival value related to burying behavior in queen conch Strombus gigas. Fish Bull 88:383-387

Kanciruk P, Herrnkind W (1978) Mass migration of spiny lobster, Panulirus argus (Crustacea: Palinuridae): behavior and environmental correlates. Bull Mar Sci 28: 601-623

* Kough AS, Paris CB (2015) The influence of spawning periodicity on population connectivity. Coral Reefs 34: 753-757

Kough AS, Claro R, Lindeman KC, Paris CB (2016) Decadal analysis of larval connectivity from Cuban snapper (Lutjanidae) spawning aggregations based on biophysical modeling. Mar Ecol Prog Ser 550:175-190

* Le Corre N, Johnson LE, Smith GK, Guichard F (2015) Patterns and scales of connectivity: temporal stability and variation within a marine metapopulation. Ecology 96: 2245-2256

Lipcius RN, Eggleston DB, Schreiber SJ, Seitz RD and others (2008) Importance of metapopulation connectivity to restocking and restoration of marine species. Rev Fish Sci 16:101-110

* McCarthy K (2007) A review of queen conch (Strombus gigas) life-history. Southeast Data, Assessment and Review (SEDAR) 14-DW-4. SEDAR, North Charleston, SC. http://sedarweb.org/docs/S14DW04\%20Conch\%20life \%20history.pdf (accessed 1 September 2016)

* Mumby PJ, Harborne AR, Brumbaugh DR (2011) Grouper as a natural biocontrol of invasive lionfish. PLOS ONE 6: e21510

* Nanninga GB, Saenz-Agudelo P, Zhan P, Hoteit I, Berumen ML (2015) Not finding Nemo: limited reef-scale retention in a coral reef fish. Coral Reefs 34:383-392

Nickols KJ, White JW, Largier JL, Gaylord B (2015) Marine population connectivity: reconciling large-scale dispersal and high self-retention. Am Nat 185:196-211

*Pinsky ML, Palumbi SR, Andréfouët S, Purkis SJ (2012) Open and closed seascapes: Where does habitat patchi- 
ness create populations with high fractions of selfrecruitment? Ecol Appl 22:1257-1267

Puckett BJ, Eggleston DB (2016) Metapopulation dynamics guide marine reserve design: importance of connectivity, demographics, and stock enhancement. Ecosphere 7: e01322

Ray M, Stoner AW, O'Connell SM (1994) Size-specific predation of juvenile queen conch Strombus gigas: implications for stock enhancement. Aquaculture 128:79-88

Saenz-Agudelo P, Jones GP, Thorrold SR, Planes S (2012) Patterns and persistence of larval retention and connectivity in a marine fish metapopulation. Mol Ecol 21: 4695-4705

Siegel DA, Mitarai S, Costello CJ, Gaines SD, Kendal BE, Warner RR, Winters KB (2008) The stochastic nature of larval connectivity among nearshore marine populations. Proc Natl Acad Sci USA 105:8974-8979

Sluka R, Chiappone KM, Wright R (1997) The benefits of a marine fishery reserve for Nassau grouper Epinephelus striatus in the central Bahamas. Proc Int Coral Reef Symp 2:1961-1964

Stoner AW (1997) Shell middens as indicators of long-term distributional pattern in Strombus gigas, a heavily exploited marine gastropod. Bull Mar Sci 61:559-570

Stoner AW (2003) What constitutes essential nursery habitat for a marine species? a case study of habitat form and function for queen conch. Mar Ecol Prog Ser 257:275-289

Stoner AW (2015) Sand bores survey. Community Conch report for the Bahamas Department of Marine Resources. www.communityconch.org/our-research/get-the-report/ (accessed 1 September 2016)

Stoner AW, Ray M (1996) Queen conch, Strombus gigas, in fished and unfished locations of the Bahamas: effects of a marine fishery reserve on adult, juveniles, and larval production. Fish Bull 94:551-565

Stoner AW, Ray-Culp M (2000) Evidence for Allee effects in

Editorial responsibility: Romuald Lipcius,

Gloucester Point, Virginia, USA an over-harvested marine gastropod: density-dependent mating and egg production. Mar Ecol Prog Ser 202: 297-302

Stoner AW, Schwarte KC (1994) Queen conch, Strombus gigas, reproductive stocks in the central Bahamas: distribution and probably sources. Fish Bull 92:171-179

Stoner AW, Mehta N, Ray-Culp M (1998) Mesocale distribution patterns of queen conch (Strombas gigas Linne) in Exuma Sound, Bahamas: links in recruitment from larvae to fishery yields. J Shellfish Res 17:955-969

Stoner AW, Mueller KW, Brown-Peterson NJ, Davis MH, Booker CJ (2012a) Maturation and age in queen conch (Strombus gigas): urgent need for changes in harvest criteria. Fish Res 131-133:76-84

Stoner AW, Davis MH, Booker CJ (2012b) Negative consequences of Allee effect are compounded by fishing pressure: comparison of queen conch reproduction in fishing grounds and a marine protected area. Bull Mar Sci 88: 89-104

* Stoner AW, Davis MH, Booker CJ (2012c) Abundance and population structure of queen conch inside and outside a marine protected area: repeat surveys show significant declines. Mar Ecol Prog Ser 460:101-114

Thomas L, Kennington WJ, Stat M, Wilkinson SP, Kool JT, Kendrick GA (2015) Isolation by resistance across a complex coral reef seascape. Proc Biol Sci 282:20151217

Thompson WL (2004) Sampling rare or elusive species: concepts, designs, and techniques for estimating population parameters. Island Press, Washington, DC

White JW, Schroeger J, Drake PT, Edwards CA (2014) The value of larval connectivity information in the static optimization of marine reserve design. Conserv Lett 7 : 533-544

Wood S, Baums IB, Paris CB, Ridgwell A, Kessler WS, Hendy EJ (2016) El Niño and coral larval dispersal across the eastern Pacific marine barrier. Nat Commun 7:12571

Submitted: September 20, 2016; Accepted: April 16, 2017 Proofs received from author(s): May 29, 2017 